The Natural Gas Market 



\title{
The Natural Gas Market
}

\section{Sixty Years of Regulation}

\author{
and Deregulation
}

\author{
Paul W. MacAvoy
}

Yale University Press

New Haven and London 
Copyright (C) 2000 by Yale University.

All rights reserved.

This book may not be reproduced, in whole or in part, including illustrations, in any form (beyond that copying permitted by Sections I07 and Io8 of the U.S. Copyright Law and except by reviewers for the public press), without written permission from the publishers.

Set in Adobe Garamond and Stone Sans type by The Composing Room of Michigan, Inc.

Printed in the United States of America.

Library of Congress Cataloging-in-Publication Data

MacAvoy, Paul W.

The natural gas market: sixty years of regulation and deregulation / Paul W. MacAvoy.

p. $\mathrm{cm}$.

Includes bibliographical references and index.

ISBN 0-300-0838I-5 (cloth : alk. paper)

I. Natural gas - Law and legislation - United States - History. 2. Deregulation-United States-History. I. Title: The natural gas market: sixty years of regulation and deregulation. II. Title.

$\mathrm{KF}_{2130} \cdot \mathrm{M}_{33} \quad 200 \mathrm{I}$

$343.73^{\prime} 0772-\mathrm{dc} 21$

$00-040837$

A catalogue record for this book is available from the British Library.

The paper in this book meets the guidelines for permanence and durability of the Committee on Production Guidelines for Book Longevity of the Council on Library Resources.

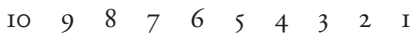


To William E. Simon, who perceived the problem very early on: writing in 1977 in A Time for Truth, "It is with inexpressible indignation that I report here that while this book was being written we had our next energy crisis, a frightening shortage of natural gas in the coldest winter in 100 years. Natural gas was concentrated, of course, in those states where the free market price existed and ran short in those states where federal price controls had reduced the supply. . . . Had anything been learned at all?" 
